Table 2. Reaction products in alkaline earth hydroxide solutions under hydrothermal conditions up to $300^{\circ} \mathrm{C}$.

\begin{tabular}{|c|c|c|c|c|c|}
\hline & $\mathrm{A}_{2}{ }_{2}{ }_{3}$ & $\mathrm{Ga}_{2} \mathrm{O}_{3}$ & $\mathrm{In}_{2} \mathrm{O}_{3}$ & $\mathrm{Cr}_{2} \mathrm{O}_{3}$ & $\mathrm{Fe}_{2} \mathrm{O}_{3}$ \\
\hline $\mathrm{Ca}(\mathrm{OH})_{2}$ & H.G. ${ }^{10)}$ & - & - & H.G. ${ }^{6)}$ & 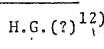 \\
\hline $\mathrm{Sr}(\mathrm{OH})_{2}$ & H.G.6) & H.G. ${ }^{6)}$ & H.G. ${ }^{13)}$ & H.G. ${ }^{6)}$ & H.G. ${ }^{6)}$ \\
\hline $\mathrm{Ba}(\mathrm{OH})_{2}$ & $x^{*}$ & $x^{143}$ & H.G. ${ }^{14)}$ & $x^{*}$ & $\mathrm{Ba} \cdot \mathrm{Fe}^{2), 4)}$ \\
\hline
\end{tabular}

H.G.; Hydrogarnet (Cubic, Ia3d)

$\mathrm{Ba} . \mathrm{Fe} ; \mathrm{BaO} .2 \mathrm{Fe}_{2} \mathrm{O}_{3}$ (Hexagpnal, $\mathrm{P}_{3} / \mathrm{m}$ )

$X$; No reaction was observed.

*; Present author.

hydroxide solutions are summarized in Table 2. Although strontium hydrogarnets are formed widely, barium hydrogarnets have not yet been found to be formed except Ba-Inhydrogarnet. Barium ion may be too large to go into dodecahedral site formed by eight hydroxyl ions and have a trend toward forming hexagonally packed or hexagonally closepacked layers together with nine or twelve oxygen ions, as is seen in the structure of $\mathrm{BaAl}_{2} \mathrm{O}_{4}{ }^{10}$ ) or $\mathrm{BaO} \cdot 2 \mathrm{Fe}_{2} \mathrm{O}_{3}{ }^{2}$, respectively. It was found also that when chromium hydroxide gel is heated with barium hydroxide solution at $350^{\circ} \mathrm{C}$, the formation of barium chromate, $\mathrm{BaCr}_{2} \mathrm{O}_{4}$, was observed.
Acknowledgement The author expresses his sincere thanks to Dr. H. Sekizawa for his helpful discussion and to Dr. T. Okada for Mössbauer spectrum measurements, both the staff scientists of the Institute of Physical and Chemical Research. The author is also much indebted to Mrs. S.I. Okamoto and Mr. D. Hashimoto for carrying out experimental parts of the work.

\section{References}

1) S. Okamoto, S.I. Okamoto and T. Ito, Acta Cryst., B 28, 1774-77 (1972).

2) S. Okamoto, S.I. Okamoto and T. Ito, Acta Cryst., B 29, 832-38 (1973).

3) K. Kitahama and R. Kiriyama, Bull. Chem. Soc. Japan, 49, 2748-54 (1976).

4) S. Okamoto, H. Sekizawa and S.I. Okamoto, J. Phys. Chem. Solids, 36, 591-95 (1975).

5) R.W.G. Wyckoff, "Crystal Structures", Vol. III, John Wiley (1965) p. 398.

6) H. Schwarz, Z. Naturforsch., B 22, 554-56 (1967).

7) J. Goodenough, "Magnetism and Chemical Bond", Interscience Publishers, New York (1963) p. 184.

8) S. Okamoto and T. Takei, Rikagaku Kenkyusho Hokoku, 36, 700-05 (1960).

9) S. Okamoto, H. Sekizawa and S.I. Okamoto, "Reactivity of Solids", Edit. J.S. Anderson et al., Chapman and Hall Ltd., London (1972) p 341-53.

10) C. Do-Dihn, E.F. Bertaut and J. Chappert, J. Phys., 30, 566-78 (1969).

11) E.P. Flintetal, H.F. McMurdie and L.S. Wells, J. Res. Nat. Bur. Stand., 26, 13-33 (1941).

12) J. Ito and C. Frondel, Am. Min., 52, 1105-09 (1967).

13) J. Ito, Am. Mineral., 53, 1663-73 (1968).

14) W. Kwestroo, H.C.A. van Gerven and H.A.M. van Hal, Mater. Res. Bull., 12, 161-64 (1977).

\title{
Preferred Orientation of Plate-like Particles in Reflection-type Powder Diffractometry
}

\author{
Yoshito TAKAKI and Hiroshi YAMAGUCHI* \\ ( Department of Physics, Osaka Kyoiku University \\ 4-88, Minami-Kawahori-cho, Tennoji-ku, Osaka-shi, 543 \\ * Department of Earth Science (Mineralogy), Osaka Kyoiku University)
}

A distribution function characterizing orientation of plate-like powder particles is presented for a usual reflection-type diffractometry when the crystal structure of the specimen has been known. An application of the treatment to the case of $\mathrm{Li}_{2} \mathrm{MSiO}_{4}(\mathrm{M}=\mathrm{Mg}, \mathrm{Fe}, \mathrm{Co}, \mathrm{Zn})$ powders is given, and it is found that the orientation distribution function can be well approximated by an expression of the form, $N(\alpha)=C_{0}+C_{1}\left\{1 /\left[1+p \alpha^{2}\right]+1 /\left[1+p(\pi-\alpha)^{2}\right]\right\}$, where $p, C_{0}, C_{1}$ are parameters and $\alpha$ is an angle between the plane of preferred orientation of a particle and that of the sample-holder. It is also shown that the observed diffraction intensities for $\mathrm{Li}_{2} \mathrm{MSiO}_{4}$ powders are satisfactorily corrected for preferred orientation by using the above expression.

[Received April 30, 1981] 


\title{
反射型粉末回折法における板状試料の選択配向性
}

\author{
高木 義人・山口弘* \\ $\left(\begin{array}{cc}\text { 大阪教育大学 } & \text { 物理学教室 } \\ * \text { 大循育大学 } & \text { 地学教室 }\end{array}\right)$
}

反射型粉末 X線回折法において, 試料の結晶構造が分っている場合, 回折強度の実測值と計算値 を比べることにより板状粉末試料の選択配向性を求好方法を与光た。この方法を $\mathrm{Li}_{2} \mathrm{MSiO}_{4}(\mathrm{M}=$ $\mathrm{Mg}, \mathrm{Fe}, \mathrm{Co}, \mathrm{Zn})$ 試料に適用し，これらの粉末試料の選択配向性が式， $N(\alpha)=C_{1}+C_{2}\left\{1 /\left[1+p \alpha^{2}\right]\right.$ $\left.+1 /\left[1+p(\pi-\alpha)^{2}\right]\right\}$, でうまく近似されることを示した。ここで $p, C_{1}, C_{2}$ はパラメーターを, めは粉末の配向面と少ンプルホールダの面とのなす角を示す.上式を使い, $\mathrm{Li}_{2} \mathrm{MSSO}_{4}$ 試料の回折 強度の補正を行ったところ非常によい結果を得た。

[1981 年 4 月 30 昌受付]

Key-words : Preferred orientation, X-ray powder diffractometry, $\mathrm{Li}_{2} \mathrm{M}^{2}+\mathrm{SiO}_{4}$

\section{Introduction}

Yamaguchi $^{1)}$ has suggested that the (010) planes of $\mathrm{Li}_{2} \mathrm{MSiO}_{4}(\mathrm{M}=\mathrm{Mg}, \mathrm{Fe}, \mathrm{Co}, \mathrm{Zn})$ powders packed into a sample-holder have a tendency to remain parallel to the plane of the sample-holder, which was examined by comparing observed intensities measured from diffractometer powder patterns with calculated intensities. This paper describes a treatment for determining the orientation distribution function for preferentially oriented plate-like powder particles in the case where a usual reflection-type counter-diffractometer is used to collect intensity data for the diffracted Xray beams.

\section{Orientation distribution function}

Let the spatial distribution of directions normal to the (010) planes of plate-like powder particles be cylindrically symmetrical about the direction, $\vec{n}$, normal to the plane of the sampleholder. Then the fractional number of particles lying in an element of solid angle $\mathrm{d} \Omega$ at an angle $\alpha$ to $\vec{n}$ is given by $N(\alpha) \mathrm{d} \Omega$, where $N(\alpha)$ is an orientation distribution function and is normalized by writing ${ }^{2)}$

$$
2 \pi \int_{0}^{\pi} N(\alpha) \sin \alpha \mathrm{d} \alpha=1
$$

Further, if the spatial distribution of directions normal to the $(h k l)$ planes of particles has a plane of symmetry perpendicular to $\vec{n}$, function $N(\alpha)$ is symmetrical about $\alpha=\pi / 2^{3}$. Equation (1) is then rewritten by

$$
4 \pi \int_{0}^{\pi / 2} N(\alpha) \sin \alpha \mathrm{d} \alpha=1
$$

The following discussion is confined to this distribution function since the above preferred orientation of particles is commonly seen in usual powder diffractometric work.

If one can measure the intensity, $I_{\mathrm{k}}(\alpha)$, for a $0 k 0$ refiection from the particles of which the directions normal to the (010) planes make an angle $\alpha$ with $\vec{n}$, function $N(\alpha)$ may be obtained by using the relation that $N(\alpha)$ is proportional to $I_{\mathrm{k}}(\alpha)$, giving ${ }^{4)}$

$$
N(\alpha)=I_{\mathrm{k}}(\alpha) / \int_{0}^{\pi / 2} 4 \pi I_{\mathrm{k}}\left(\alpha^{\prime}\right) \sin \alpha \mathrm{d} \alpha
$$

In our case, however, we cannot measure $I_{\mathrm{k}}(\alpha \neq 0)$ directly since the reflection geometry for the above-mentioned reflection-type diffractometry allows the incident X-ray beams to reflect only when the reflecting plane is parallel to the plane of the sample-holder. Function $N(\alpha)$ is then obtained from the following procedure.

Let a dircetion normal to the ( $h k l)$ plane (hereinafter given simply as direction $(h k l)$ ) make an angle $\alpha$ with direction (010), and consider the particles having direction (010) lying at angles between $\alpha$ and $\alpha+\mathrm{d} \alpha$ to $\vec{n}$. Then the fractional number of the particles contained in an element of solid angle, sin $\alpha \mathrm{d} \alpha \mathrm{d} \phi$, in a circular band SQ (see Fig. 1) is $N\left(\alpha^{\prime}\right) \sin \alpha \mathrm{d} \alpha \mathrm{d} \phi$

where $\phi$ is an angle measured around $\vec{n}$ in a plane perpendicular to $\vec{n}$, and the particles in an element of the above solid angle at Q, for instance, will produce a distribution of directions ( $h k l$ ) over the circular band PR of an angle range $\mathrm{d} \alpha$ (Fig. 1). Then we have

$$
N\left(\alpha^{\prime}\right) \sin \alpha \mathrm{d} \alpha \mathrm{d} \phi=2 \pi \mathrm{d} N^{\prime} \sin \alpha \mathrm{d} \alpha
$$

where $d N^{\prime}$ is a distribution density of direction $(h k l)$. Equation (4) leads to

$$
\mathrm{d} N^{\prime}=(2 \pi)^{-1} N(\alpha) \mathrm{d} \phi
$$




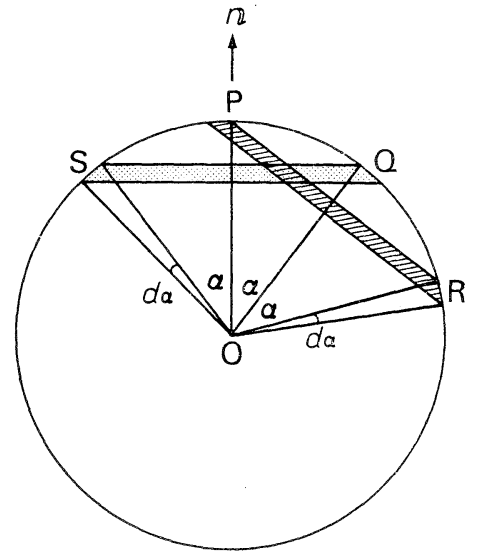

Fig. 1. Geometrical relationship between two circular bands, SQ and PR, each having an angle range $\mathrm{d} \alpha$.

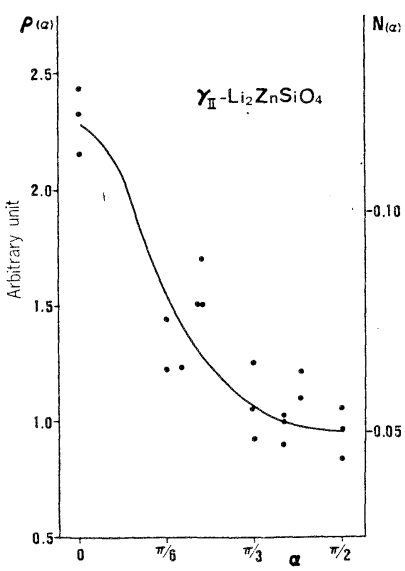

(a)

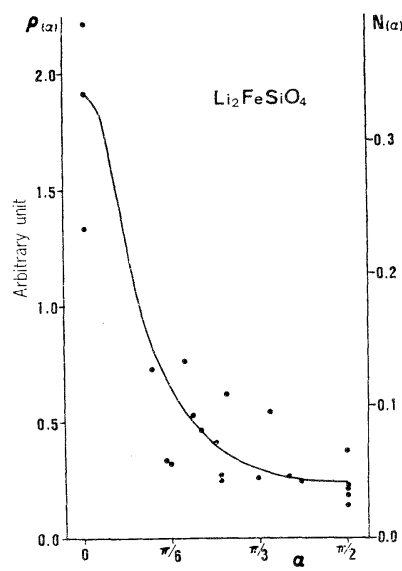

(b)

Fig. 2. Distributions of $\rho(\alpha)$ vs $\alpha$ for (a) $\gamma_{\mathrm{II}}-\mathrm{Li}_{2} \mathrm{ZnSiO}_{4}$ and (b) $\mathrm{Li}_{2} \mathrm{FeSiO}_{4}$. The solid curves give the orientation distribution functions $N(c)$ determined by Equation (10).

Since $\phi$ measures around $\vec{n}$, function $N(\alpha)$ is independent of $\phi$. Hence

$$
\begin{aligned}
N^{\prime} \text { at } P & =(2 \pi)^{-1} N(\alpha) \int_{0}^{2 \pi} \mathrm{d} \phi \\
& =N(\alpha)
\end{aligned}
$$

That is, function $N(\alpha)$ can be determined from the orientation distribution density for direction $(h k l)$ measured at $\stackrel{P}{ }$.

Then, if the crystal structure of the specimen has been known, function $N(\alpha)$ may be obtained from the following expression :

$$
N(\alpha)=\rho(\alpha) / \int_{0}^{\pi / 2} 4 \pi \rho(\alpha) \sin \alpha d \alpha
$$

with

$$
\rho(\alpha)=I_{0}(\alpha) / I_{\mathrm{c}}(\alpha)
$$

where $I_{0}(\alpha)$ and $I_{c}(\alpha)$ are respectively observed with preferred orientation and calculated without preferred orientation correction intensities for a $h k l$ reflection of which the $(h k l)$ plane makes an angle $\alpha$ with the (010) plane.

\section{Application to $\mathrm{Li}_{2} \mathrm{MSiO}_{4}$ powders}

Figure 2 (a) shows the distribution of $\rho(\alpha)$ as a function of $\alpha$ for $\gamma_{\mathrm{II}}-\mathrm{Li}_{2} \mathrm{ZnSiO}_{4}{ }^{1{ }^{1,5}}$, where twenty observed reflections havings ingle or clearly distinguishable peaks in the powder diffraction pattern are used to obtain $\rho(\alpha)$. From Fig. 2 (a) one may clearly see that the (010) planes have a tendency to be preferentially oriented, even though the variation of the values of $\rho(\alpha)$ for a given $\alpha$ is significantly large. This large variation would be mainly due to inaccuracy of observed intensities.

Two idealized expressions of Gaussian and
Cauchy types were examined to represent $N(\alpha)$ in analytical form. They are :

$$
\begin{aligned}
N(\alpha)= & C_{0}+C_{1}\left\{\exp \left[-p \alpha^{2}\right]\right. \\
& \left.+\exp \left[-p(\pi-\alpha)^{2}\right]\right\}
\end{aligned}
$$

and

$$
\begin{aligned}
N(\alpha)= & C_{0}+C_{1}\left\{1 /\left[1+p \alpha^{2}\right]\right. \\
& \left.+1 /\left[1+p(\pi-\alpha)^{2}\right]\right\}
\end{aligned}
$$

where $p$ represents degree of preferred orientation, and $C_{0}, C_{1}$ are constants normalized by Equation (2). Of the above two expressions, we found that Equation (10) gives a good approximation with the values $p=3.14$, $C_{0}=0.0300$ and $C_{1}=0.0873$. In Fig. 2(a), function $N(\alpha)$ is compared with the distribution of $\rho(\alpha)$.

It is to be noted that the observed intensities for $\gamma_{\mathrm{II}}-\mathrm{Li}_{2} \mathrm{ZnSiO}_{4}$ can be satisfactorily corrected for preferred orientation by using $N(\alpha)$ given above; the $R$ values for the 20 reflections before and after correction are 0.12 and 0.06 respectively, where $R=\sum|| F_{\mathrm{o}}\left|-F_{\mathrm{c}} \| / \sum\right| F_{\mathrm{o}} \mid, F_{\mathrm{o}}$ and $F_{\mathrm{c}}$ being observed and calculated structure factors.

Figure $2(\mathbf{b})$ shows the distribution of $\rho(\alpha)$ as a function of $\alpha$ for $\mathrm{Li}_{2} \mathrm{FeSiO}_{4}{ }^{67},{ }^{7)}$ together with $N(\alpha)$ determined by Equation (10), the values of $p, C_{0}$ and $C_{1}$ being $9.12,0.0141$ and 0.3184 , respectively. The $R$ values before and after correction for preferred orientation are 0.33 and 0.13 , respectively.

Similarly, functions $N(\alpha)$ for $\beta_{\mathbb{I I}^{-}}$ $\mathrm{Li}_{2} \mathrm{CoSiO}_{4}{ }^{1)}{ }^{18}, \beta_{\mathrm{II}}-\mathrm{Li}_{2} \mathrm{ZnSiO}_{4}{ }^{1)}, \gamma_{\mathrm{II}}-\mathrm{Li}_{2} \mathrm{MgSiO}_{4}{ }^{1{ }^{1}}$ and $r \mathrm{II}-\mathrm{Li}_{2} \mathrm{CoSiO}_{4}{ }^{1)}$ are obtained as $p=2.34$, $C_{0}=0.0333$ and $C_{1}=0.0611, p=2.34, C_{0}=$ 
0.0245 and $C_{1}=0.0977, p=1.76, C_{0}=0.179$ and $C_{1}=0.0977$ and $p=2.39, C_{0}=0.0231$ and $C_{1}=0.0985$, respectively.

Note that in the determination of the values of $p, C_{0}$ and $C_{1}$ for the former two $\beta_{\mathrm{II}}$ phases, the reflections with $k$ odd were all excluded from the calculation because their profiles of powder patterns were remarkably broadened due to the effect of structural disorder ${ }^{9}$.

In conclusion, we may say that Equation (10) given above is useful to correct observed intensities for the effect of preferred orientation in refining crystal structures of preferentially oriented powder samples.

Acknowledgement The authors thank Professor K. Sakurai for his continued interest and encouragement. One of the authors (H.Y.) also thanks Professor K.
Akatsuka for his valuable advises.

\section{References}

1) H. Yamaguchi, Yogyo-Kyokai-Shi, 89, 203-08 (1981).

2) R.D.B. Fraser, T.P. Macrae, A. Miller and R.J. Rowlands, J. Appl. Cryst., 9, 81-93 (1976).

3) E. Sturm and W. Lodding, Acta Cryst., A 24, 650 -53 (1968).

4) A. Plançon, J. Appl. Cryst., 13, 524-28 (1980).

5) H. Yamaguchi, K. Akatsuka and M. Setoguchi, Acta Cryst., B 35, 2678-80 (1979).

6) M. Setoguchi, S. Kobayashi, H. Yamaguchi, C. Sakamoto and K. Akatsuka, Mem. Osaka Kyoiku Univ. Ser., III, 28, 27-36 (1979).

7) H. Yamaguchi, K. Akatsuka and M. Setoguchi, Mem. Osaka Kyoiku Univ. Ser., III, 28, 37-45 (1979).

8) H. Yamaguchi, K. Akatuska, M. Setoguchi and Y. Takaki, Acta Cryst., B 53, 2680-82 (1979).

9) Y. Takaki and H. Yamaguchi, Acta, Cryst., B 36, 224-37 (1980).

実験・技術・調查報告・Report

\section{酢酸液滴を用いるマグネシア多泡粒の調製 (マグネシア多泡粒の研究，その 1)}

本江秋弘・和波達夫* 一 石堂善彦・桝川卓哉*

長 田 清・藤井欽二郎

$\left(\begin{array}{c}\text { 化学技術研究所 } \\ * \text { イソライト工業(株) }\end{array}\right)$

マグネシアの多泡粒またはペレットは，マグネシアと酰酸との発熱反応による沸騰一固化の現象 を利用して調製することができる. 実験用の装置として, マグネシア粉末層の環状ベッドを載せた 回転皿を用い，移動ベッドの表面を $140^{\circ} \sim 180^{\circ} \mathrm{C}$ に加熱し，そこに䣷酸液滴を散布してマグネシア と反応させ，生成する多泡粒をスクレーパーによってベッドから掻き取る. 加熱用に用いたシュバ ンクバーナからマグネシア粉末ベッドへの複合伝熱係数は $30.8 \mathrm{kcal} /\left(\mathrm{m}^{2} \cdot \mathrm{h} \cdot{ }^{\circ} \mathrm{C}\right)$ であった. スプレ 一ノズルから散布される液滴は直径 $0.5 \sim 5 \mathrm{~mm}$ の間で粒度分布をもつような多泡粒に変化し, ま た造粒容量は回転ベッド 1 平方メートル当たり約 $0.3 \mathrm{~kg}$ であった. スクレーパーは振動ふるい形 式のもので, ベッド層から選択的に多泡粒を分離した。ベッドの表面温度 $180^{\circ} \mathrm{C}$ で媈転した場合の 酢酸の損失は, 全使用量の $28 \%$ で, 本法のプロ七ス化を考慮して, 蒸発損失する酢酸分の回収に も言及した。

(1981 年 4 月 18 日受付)

\section{Preparation of Porous Magnesia Grains by Use of Acetic Acid Droplets}

(Study on Porous Magnesia Grains, Part 1)

Akihiro MOTOE, Tatsuo WANAMI*, Yoshihiko ISHIDO,

Takuya MASUKAWA*, Kiyoshi OSADA and Kinjiro FUJII

( National Chemical Laboratory For Industry)

Yatabe, Ibarki 305

* Isolite Insulating Products Co. 